\title{
Article \\ Quantifying Advantages of Modular Construction: Waste Generation
}

\author{
Loizos Loizou ${ }^{1}$, Khalegh Barati ${ }^{1, *}$, Xuesong Shen ${ }^{1}$ and Binghao Li ${ }^{2}$ \\ 1 School of Civil and Environmental Engineering, University of New South Wales, \\ Sydney, NSW 2052, Australia; 1.loizou@unsw.edu.au (L.L.); x.shen@unsw.edu.au (X.S.) \\ 2 School of Minerals and Energy Resources Engineering, University of New South Wales, \\ Sydney, NSW 2052, Australia; binghao.li@unsw.edu.au \\ * Correspondence: khalegh.barati@unsw.edu.au
}

Citation: Loizou, L.; Barati, K.; Shen, X.; Li, B. Quantifying Advantages of Modular Construction: Waste Generation. Buildings 2021, 11, 622. https://doi.org/10.3390/buildings 11120622

Academic Editor: Francesco Guarino

Received: 3 November 2021

Accepted: 2 December 2021

Published: 7 December 2021

Publisher's Note: MDPI stays neutral with regard to jurisdictional claims in published maps and institutional affiliations.

Copyright: (c) 2021 by the authors. Licensee MDPI, Basel, Switzerland. This article is an open access article distributed under the terms and conditions of the Creative Commons Attribution (CC BY) license (https:/ / creativecommons.org/licenses/by/ $4.0 /)$.

\begin{abstract}
The construction industry is a significant source of waste generation in any economy, producing various greenhouse gases, releasing harmful substances into the natural environment, and requiring large areas of land for processing, treatment, and landfilling. The emerging field of off-site prefabrication and assembly is perceived as a viable method to reduce waste and improve sustainability. However, there is a lack of quantifiable research into the difference between off-site prefabrication and on-site, conventional construction for numerous sustainability criteria. This paper focuses on modular construction as an off-site production system, where a framework to compare waste generation of modular and conventional, in-situ construction methods is proposed. This paper aims to quantify these differences. The framework relies on a comprehensive literature review to estimate the waste rates of building materials, which are then applied to realistic case studies in order to determine the differences in waste generation. Overall, modular construction reduces the overall weight of waste by up to $83.2 \%$, for the cases considered. This corresponds to a $47.9 \%$ decrease in the cost of waste for large structures. Care must be taken to keep modular wastage as low as possible for a reduced cost of waste to be also present in smaller structures. This reduces the research gap of quantifying the waste differences between conventional and modular construction, and provides thoroughly researched waste rates for future research, while also improving the knowledge of industry stakeholders, informing them of the benefits of modular construction. This allows stakeholders to make more informed decisions when selecting an appropriate construction method.
\end{abstract}

Keywords: construction methods; waste generation; modular construction; sustainability; building materials

\section{Introduction}

Waste generation is an issue that affects all societies globally. Based on the type of waste, it can produce various greenhouse gases, release harmful substances into the natural environment, and require large areas of land for processing, treatment, and landfilling. The construction and demolition (C\&D) industry is a major contributor of this waste. In fact, numerous studies consider waste generation to be one of, if not the most important, factor in determining the environmental sustainability of a construction project [1-5]. Globally, construction activities produce approximately $25 \%$ of all solid waste, with $40 \%$ of material in landfills a result of construction activities. Not only this, but construction waste is continuing to increase [6]. In Australia, around 30.4\% of the $67 \mathrm{Mt}$ of waste produced in 2017 was from the C\&D sector [7]. While $67 \%$ of this is recycled or reused in some way, mostly as aggregates for new road bases, continuing to increase the recycling rate of C\&D waste via conventional means becomes increasingly difficult [7]. Recycling rates of over $80 \%$ have only been exceptionally achieved in countries such as Germany and the Netherlands [8]. Reducing waste generation itself is therefore vital in reducing the environmental impact of the C\&D sector. One method perceived to achieve low waste generation and high recycling rates is to transition away from conventional, on-site 
construction and towards prefabrication and assembly $[9,10]$. Namely, by utilising modular construction, a method where three dimensional (or volumetric) modules are prefabricated and simply assembled on-site. The concept of modular construction can vary widely in industry. Bertman et al. [11] presents 12 definitions of prefabrication based on scale and complexity. Here, four levels of scale include (1) individual units; (2) individual panels; (3) volumetric units; and (4) complete structures. For each scale, there are then three levels of complexity, which range from (1) largely structural, to (2) fitted with limited fixtures, to (3) fully functional with complete fixtures. Prefabricating structures in larger scales requires less assembly, while prefabricating in greater complexity requires less on-site construction. In this paper, comparisons are made between conventional construction and the best possible prefabrication practice, which minimises on site construction and assembly. As prefabricating completed structures is highly impractical due to manufacturing and transportation constraints, "modular construction" is considered to involve volumetric units that are fully functional with complete fixtures. This definition is also reflective of Lu et al. [12], who consider volumetric structures that "form the fabric of the building structure" with fully functional fixtures as the highest level of modular construction.

In general, industry views modular construction favourably and perceives it to have numerous advantages [13-15]. In addition, the construction industry views prefabrication and modular construction as an effective method to reduce waste generation. Wang et al. [9] demonstrates that "prefabricated components" and "modular design" are the first and fifth most important perceived factors in minimising construction waste. This reinforces earlier studies by Jaques [10], which found that "modular design" is perceived as the second and third most effect measures to reduce waste by architects and quantity surveyors, respectively. However, there is a lack of quantification in the differences between modular and conventional construction for many sustainability factors, and especially for waste generation (see Section 2.2). This may be a contributing factor for the low adoption rate of modular construction in many countries, such as Australia, where modular construction only represented 3\% of construction in 2016 [16].

The main research objective of this paper is therefore to quantify the difference between waste generation in modular and conventional construction methods. Other research gaps on the quantifiable difference between the methods include direct employment, traffic congestion, potential for delays, ease of construction, flexibility, supply chain integration, and aesthetic appeal and effect on physical space. As waste generation is one of the most vital factors in determining a construction project's environmental sustainability [1-5], it is selected as the focus of this research. This paper first estimates waste generation rates using a detailed literature review. These are then applied to realistic case studies to produce waste estimations for both modular and conventional construction methods. This will reduce the research gap that is present when comparing waste generation in modular and conventional construction methods. Doing so will assist both policy makers and stakeholders in selecting the most appropriate construction method for their needs, while also providing thoroughly researched waste rates for future construction project waste estimations. Overall, this study provides a valuable foundation for the quantified differences between modular and conventional construction, creating a point of reference for future research while also improving the knowledge of industry stakeholders for future construction planning.

The structure of the rest of the paper is as follows. Section 2 details prior research in the quantification of modular construction, as well as presenting both conventional and modular waste rates based on literature. Section 3 presents the research methodology and data analysis technique. Sections 4 and 5 detail the research results and critically discuss their interpretation, and provide cost saving estimations from the reduction of waste. Section 6 presents the conclusion to this research and offers limitations and recommendations for further research. 


\section{Literature Review}

This section details previous research findings on the topic of modular construction. Waste in relation to the context of this study is first defined, followed by a review on previous literature that has quantified the differences between modular and conventional construction. The waste rates for conventional and modular construction are then determined based on prior research and case studies.

\subsection{Waste Definition}

When considering waste, it is important to define several terms. For this study, quantity take-off refers to the amount of required material that will be permanently incorporated into a structure. It is the minimum amount of material needed to construct a structure and excludes (1) temporary material and equipment for the construction process, and (2) wastage. Waste refers to the amount of material used to construct a structure that is in excess of the quantity take-off, using a mass balance approach as defined by Li et al. [17] A material loss rate (MLR) then refers to the amount of waste as a fraction of quantity take-off, represented as a percentage, as shown in Equation (1). By this definition, excess material that is incorporated into a structure (such as excess steel reinforcement in concrete elements) is still considered to be waste. Total material refers to the summation of the quantity take-off and waste, representing the actual amount of material required to construct a structure.

$$
M L R_{i}=\frac{\sum_{i}(\text { Total material })-\sum_{i}(\text { Quantaty take }- \text { off })}{\sum_{i}(\text { Quantaty take }- \text { off })} \%
$$

\subsection{Modular Construction Benefit Quantification}

Table 1 shows a summary of recent literature in quantifying the differences between modular and conventional construction. Overall, there is significant research regarding economic sustainability. Prior research shows that when modular construction is adopted, construction time and labour costs are reduced; however, material costs are increased. These labour savings have the potential to reduce the overall cost of a project, provided that they are utilised effectively and that the increased material costs are managed and minimised [5,11,18-20].

There is also significant research into the quantification of environmental sustainability. Recent literature shows that modular construction reduces the required energy for construction, greenhouse gas emissions, and embodied carbon. However, material consumption is increased [5,18-22]. Quale et al. [23] also studied the differences in modular and conventional construction in relation to greenhouse gas emissions, acidification, carcinogens, non-carcinogens, criteria pollutants, eutrophication, ecotoxicity, water usage, and ozone depletion, and found that modular construction performed favourably in all categories except for eutrophication and water usage.

While it is still somewhat lacking, there is also a reasonable amount of research into social sustainability. Recent studies show that modular construction produced a less hazardous environment, reduced injury severity, and lowered noise levels on-site [18,19]. However, Dabirian et al. [24] demonstrated that prefabrication facilities produce higher decibels of noise than both modular and traditional on-site activities. Despite this, noise is more controlled to outside sources, thus reducing community disturbance.

Table 1. Summary of previous literature on quantifying modular construction.

\begin{tabular}{cc}
\hline Researcher(s) & Results \\
\hline Dabirian et al. [24] & Prefabrication facilities produce more noise than on-site construction. \\
\hline Bertman et al. [11] & $\begin{array}{c}\text { Construction times can be reduced by } 50 \% \text {. Reduced labour costs can outweigh } \\
\text { increased material costs and reduce overall cost by } 20 \% .\end{array}$ \\
\hline
\end{tabular}


Table 1. Cont.

\begin{tabular}{|c|c|}
\hline Researcher(s) & Results \\
\hline Ferdous et al. [25] & $\begin{array}{l}\text { Modular construction results in better integration of supply chains; however, } \\
\text { requires high investment costs as well as additional project planning. The modular } \\
\text { industry in Australia will grow form 3\% of construction in } 2016 \text { to } 5-10 \% \text { by } 2030 \text {. }\end{array}$ \\
\hline Hammad et al. [18] & $\begin{array}{l}\text { Modular construction reduces embodied energy by } 56 \% \text { and } 26 \% \text { in small and } \\
\text { large structures, respectively, and decreases construction time and speeds up the } \\
\text { return on investment. }\end{array}$ \\
\hline Kamali and Hewage [4] & $\begin{array}{l}\text { Modular construction increases material consumption, reduces construction time, } \\
\text { reduces labour cost and delivers a higher quality and more durable structure. }\end{array}$ \\
\hline Aye et al. [21] & $\begin{array}{l}\text { A steel prefabrication system can reduce material consumption by up to } 78 \% \text { when } \\
\text { compared to conventional reinforced concrete construction; however, a } 50 \% \\
\text { increase in embodied energy was observed. }\end{array}$ \\
\hline Lawson et al. [26] & $\begin{array}{l}\text { Modular construction reduces safety incidents by up to } 80 \% \text {, noise by } 30-50 \% \text {, } \\
\text { delivery vehicle frequency by up to } 70 \% \text {, and embodied energy, while also } \\
\text { improving acoustic insulation and thermal performance. }\end{array}$ \\
\hline Quale et al. [23] & $\begin{array}{c}\text { Modular construction increases water usage and eutrophication, and decreases } \\
\text { greenhouse gas emissions, acidification, carcinogens, non-carcinogens, criteria } \\
\text { pollutants, ecotoxicity, smog, and ozone depletion. }\end{array}$ \\
\hline Monahan and Powell [22] & Modular construction reduces embodied carbon by $34 \%$ cradle to site. \\
\hline Al-Hussein et al. [19] & $\begin{array}{l}\text { Modular construction reduces direct emissions by } 43 \% \text {, minimises injuries due to } \\
\text { falls, and causes a } 10-30 \% \text { cost reduction due to productivity increase and reduced } \\
\text { maintenance cost due to improved structure 'tightness.' }\end{array}$ \\
\hline Baldwin et al. [20] & $\begin{array}{l}\text { There is little difference between modular and conventional overall costs; however, } \\
\text { there is potential for cost reduction due to labour cost reduction. }\end{array}$ \\
\hline Kim [27] & $\begin{array}{l}\text { Modular construction produces less waste and uses less energy over its lifespan } \\
\text { and during the extraction, production, transport, and construction stages. }\end{array}$ \\
\hline
\end{tabular}

In addition to the above, Navaratnam et al. [28] identified that modular structures can have greater fire resistance and acoustic performance, and, when constructed to resist earthquake and high wind loading, performs better than conventional structures designed against these forces. Wang et al. [29] also pointed out that off-site construction is an effective method, when incorporated with Building Information Modelling, RFID and GPS systems, the Internet of Things, and other technologies, to bring the construction industry in line with "Industry 4.0." This is known as a new phase of industry that focuses heavily of increasing production and reducing risks through interconnectivity, automation, machine learning, and use of real-time data.

Previous studies comparing modular and conventional waste generation do exist. As outlined previously, several studies indicate how the industry views prefabrication and modular construction as effective methods for reducing waste $[9,10]$. However, these studies are based on expert opinion only, with waste improvements being measured qualitatively, rather than quantitatively. More in-depth studies also measure waste qualitatively. Baldwin et al. [20] identifies the potential for prefabrication to reduce waste in Hong Kong through the reduction or elimination of steelwork, falsework, formwork, etc, identifying that these are the sources of over $80 \%$ of construction waste. Monahan and Powell [22] use a life cycle approach to compare embodied carbon and energy in modular and conventional houses, and, while it is found that waste is reduced in the modular case, the paper asserts that "the waste data collected, from both MMC [Modern Methods of Construction] and the on-site construction, was not of sufficient quality to make a robust quantification." Jaillon and Poon [30] studied two projects in Hong Kong with significant prefabrication (a 17 story tower with $47 \%$ precast volume, and two 14 story towers linked with a podium with $40 \%$ precast volume) and found that "reduction of construction waste" was ranked as the highest advantage by respondents when compared to other projects with less prefabri- 
cation. Similarly, a previous study by Jaillon and Poon [31] found that "waste reduction" was considered the highest ranked benefit among industry respondents when comparing significantly prefabricated structures against conventional construction. This was true for a general industry survey and project specific surveys that involved significant prefabrication. The project-specific cases were also analysed in detail, and it was found that waste was reduced by $56 \%, 69 \%$, and $79 \%$ when the project was $60 \%, 50 \%$, and $57 \%$ prefabricated by volume, respectively.

Other studies also attempt to quantify the differences in waste generation when significant prefabrication is used. Jaillon et al. [32] analysed seven case studies in Hong Kong with significant prefabrication. It found that waste was reduced by $14-70 \%$ ( $52 \%$ average). However, like the previous study, case studies were only partially prefabricated, with varying prefabricated percentages in four structure components (prefabricated metal formwork, precast stairs, precast façades, and "other precast"). Other structure elements were largely conventional, with the exception of semi-precast slabs, lost form panel formwork, and semi precast balconies in three of the cases. Similarly, Tam et al. [33] analysed four case studies in Hong Kong. For each structure component (plastering, timber formwork, concrete, and reinforcement) that was replaced, to some extent, with prefabrication, waste was reduced by $35-100 \%$ for that component. The overall waste reduction of the entire structure was not considered, and the level of prefabrication for each component and the structure as a whole is unclear.

When comparing modular structures (as defined above) to conventional structures, Kim [27] uses a life cycle approach and determines that modular structures produce $60 \%$ less waste than conventional structures during the construction / fabrication phase. However, this study uses many simplifications and assumptions, including identical building materials between the methods, and only modifications to stud size, marriage walls, and folding roof trusses are present between the structures. As mentioned above, Quale et al. [23] uses a life cycle approach to compare various environmental and ecotoxicity factors between modular and conventional structures. While waste is included, and a reduction of $20.1 \%$ in the modular case is observed, the study recognises that this is for comparative purposes of the ecotoxicity factors only, and is not indicative of the true waste reduction resulting from modular construction.

Li et al. [34] expands these concepts by proposing a dynamic model that evaluates industry willingness to adopt prefabrication in China based on government policy scenarios (including subsidies, income tax benefits, or a combination of the two). Associated total waste reduction is estimated as a result of industry willingness to adopt prefabrication; however, this reduction is at a regional level. The waste reduced on a project level is not known. High variations in these estimations also exist. Other studies attempt to further reduce waste generation in prefabrication. For instance, Banihashemi et al. [6] finds that incorporating parametric designs into modular design can reduce panelling waste by a minimum of $2 \%$. This ties into the principles of lean construction, defined as the method of designing production systems to minimise waste of material, time, and effort, while still generating the maximum possible value [35]. As modular design converts construction into a manufacturing activity, its implementation is necessary for the success of modular construction. Demirkesen and Bayhan [36] determine the financial, cultural, managerial, technical, workforce, cultural, governmental, and communication factors needed for successful implementation, and finds that lean training, availability of lean tools and techniques, and market share were the most important factors for successful implementation. When implemented, lean construction as a manufacturing principle of modular construction has the potential to significantly reduce waste. Bajjou et al. [37] outlines how manufacturing is $88 \%$ productive and $12 \%$ wasteful, while conventional construction is $47 \%$ productive and $53 \%$ wasteful. Utilising manufacturing (i.e., through prefabrication and modular construction) is an effective method in reducing waste. In addition, Hosseini et al. [38] uses discrete event simulation to find that prefabrication using 
lean construction can reduce waste from reinforcing rebars by $92 \%$. However, a holistic comparison between conventional and modular structures is still required.

From this, there is a need to quantitatively compare the waste generated in fully modular structures (as defined above) with conventional structures. Previous studies tend to compare partially prefabricated structures, and even when modular structures are considered, many simplifications or assumptions are made, as waste generation is often not the focus of research. This paper therefore fulfils the need for a robust waste comparison between modular and conventional construction, first by determining modular and conventional waste rates, and then applying them to realistic case studies.

\subsection{Conventional Construction Waste Rates}

Various references provide waste rates for conventional construction. These tend to vary based on numerous factors, including structure size and type, dominant structural material, and geographical location. A summary of waste rates from numerous references can be seen in Table 2. Where waste rates were presented as a percentage of total material, they were adjusted to reflect material loss rate (as defined by Equation (1)). Some references used gross floor area (GFA) to estimate waste rates, a method of estimation based on a structure's size rather than its material type.

Table 2. Conventional construction waste rates from literature.

\begin{tabular}{|c|c|c|c|c|c|c|c|}
\hline Material & Guerra et al. [39] & Bakshan et al. [40] & Li et al. [17] & Malia et al. [41] & Lu et al. [42] & Kim [27] & Treloar et al. [43] \\
\hline Steel & - & $\begin{array}{c}1.25(0.11-7.2 \\
\text { range })\end{array}$ & $\begin{array}{l}3.09 \%(4.71 \% \\
\text { typical) }\end{array}$ & $\begin{array}{c}0.2-2.6 \\
\text { (residential) } \\
1-7.2 \\
\text { (non-residential) }\end{array}$ & $2.97 \%$ & $9.17 \%$ & $10 \%$ \\
\hline Bitumen & - & - & - & $\begin{array}{c}0.4-2.6 \\
\text { (residential) } \\
0.7-6.6 \\
\text { (non-residential) }\end{array}$ & - & - & - \\
\hline Masonry & - & $\begin{array}{c}17.44(3.4-58.6 \\
\text { range })\end{array}$ & $\begin{array}{l}5.26 \%(2.04 \% \\
\text { typical) }\end{array}$ & $\begin{array}{c}19.2-58.6 \\
\text { (residential) } \\
15.6-54.3 \\
\text { (non-residential) }\end{array}$ & $7.52 \%$ & - & $5 \%$ \\
\hline Timber & - & $\begin{array}{c}4.35(0.99-7.6 \\
\text { range })\end{array}$ & - & $\begin{array}{c}2.5-6.4 \\
\text { (residential) } \\
1.7-5.4 \\
\text { (non-residential) }\end{array}$ & - & $8.28 \%$ & $10 \%$ \\
\hline Formwork & - & - & $\begin{array}{l}80 \%(100 \% \\
\text { typical) }\end{array}$ & - & $5.26 \%$ & $12.33 \%$ & - \\
\hline Tiles & - & 2 (0.33-3.2 range) & $\begin{array}{l}4.17 \%(2.04 \% \\
\text { typical) }\end{array}$ & $\begin{array}{c}1.7-3.2 \\
\text { (residential) } \\
0.4-3.2 \\
\text { (non-residential) }\end{array}$ & - & - & - \\
\hline Plasterboard & $15.98 \%$ & 0.31 (0.35-6 range) & - & $\begin{array}{c}3.7-7.6 \\
\text { (residential) } \\
2.6-6.3 \\
\text { (non-residential) }\end{array}$ & - & $5.98 \%$ & $10 \%$ \\
\hline Insulation & - & - & - & $\begin{array}{c}0.1-1.2 \\
\text { (residential) } \\
0.1-1.5 \\
\text { (non-residential) }\end{array}$ & - & - & - \\
\hline $\begin{array}{l}\text { Estimation } \\
\text { method }^{1}\end{array}$ & MLR & GFA & MLR & GFA & MLR & MLR & MLR \\
\hline
\end{tabular}

${ }^{1}$ MLR: Material Loss Rate as defined by Equation (1); GFA: Gross floor area, waste is defined as $\mathrm{kg} / \mathrm{m}^{2} \mathrm{gross}$ floor area.

\subsection{Modular Construction Waste Rates}

Unlike conventional construction, research into waste rates for modular construction is limited. As a construction technique, prefabrication would have waste rates comparable to 
manufacturing rather than construction, simply due to its nature. As outlined above, many studies acknowledge the lower waste generation potential for modular construction. For instance, Aye et al. [21] also deduced, through a literature review, that construction waste can be reduced by $52 \%$ through the minimisation of off-cuts. This is taken further by AlHussein et al. [19], who asserts that when modular construction is adopted, "theoretically, there should be no [waste] material left." Only Kim [27] recommends using a 3\% waste factor for all materials to reflect the waste rate reported at a prefabrication facility for Redman Homes located in Topeka, Indiana. It also suggests expanding this to $5 \%$ to account for material consumption sensitivity.

\section{Methodology}

In earlier sections, the waste rate of construction materials was determined for both modular and conventional construction. It is necessary to apply these waste rates to realistic case studies as an effective method to quantify the differences in waste generation [18]. For the case studies to be considered appropriate, several criteria must be satisfied. First, the outcome of the completed structure must be identical between the methods, only varying in material type and quantity. Second, the modular cases must adhere to the definition of modular construction outlined in Section 1 . That is, volumetric units that are fully functional with complete fixtures. Third, both the conventional and modular cases must either be a completed structure, a structure under construction, a structure approved for construction or must satisfy all relevant codes and standards, allowing them to be constructed in the future. The framework of this study is summarised in Figure 1.

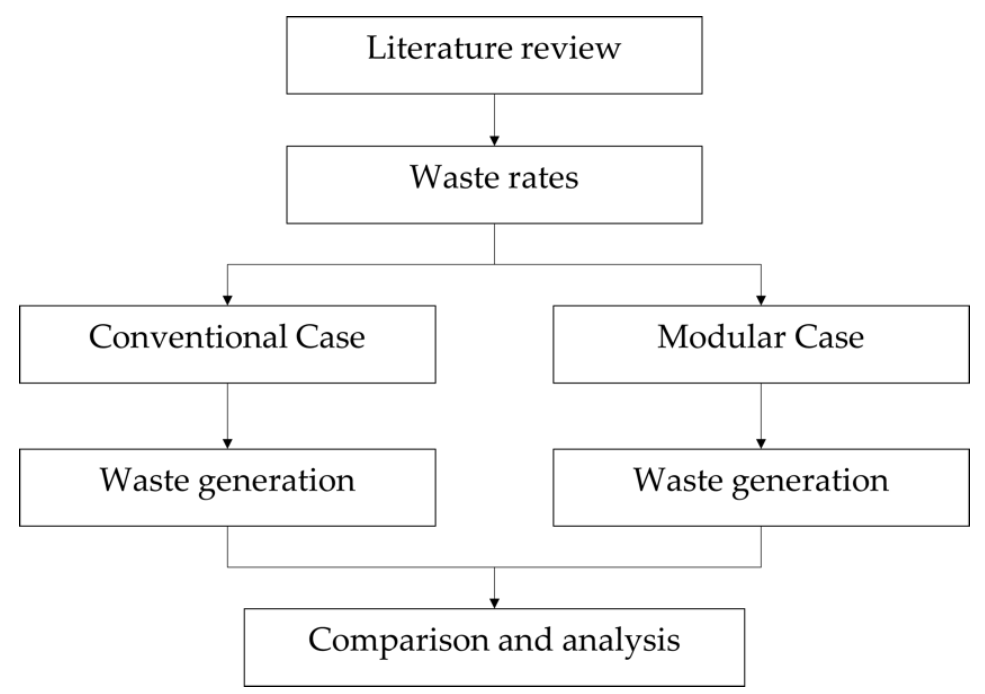

Figure 1. The research framework developed for waste generation estimation.

\subsection{Case Studies}

This study uses the two case studies from Hammad et al. [18] to provide a more reliable comparison. The first case study, Case A, is a single-story granny flat in Sydney, Australia, with a gross floor area of $63 \mathrm{~m}^{2}$. The second case study, Case B, is a three-story public school located in the Central Coast, Australia, with a gross floor area of $2220 \mathrm{~m}^{2}$ $\left(740 \mathrm{~m}^{2}\right.$ per storey). Both case studies have their floor plan shown in Figure 2, derived from Hammad et al. [18]. In both conventional cases, construction is undertaken in four stages, as outlined in Table 3. In both modular cases, the construction process is identical, and involves five stages. In stage 1, on site excavation, rolling of cold-form steel, and welding of the building chassis occurs simultaneously. In stage 2, the frame is assembled using the cold-formed steel. Then, in stage 3, hot rolled steel and the assembled cold-formed steel frames are transported to assembly points. Stage 4 involves the assembly these two elements into modules with services and finishes installed in stage 5, allowing the modules to then be ready for transport and assembly on site. 

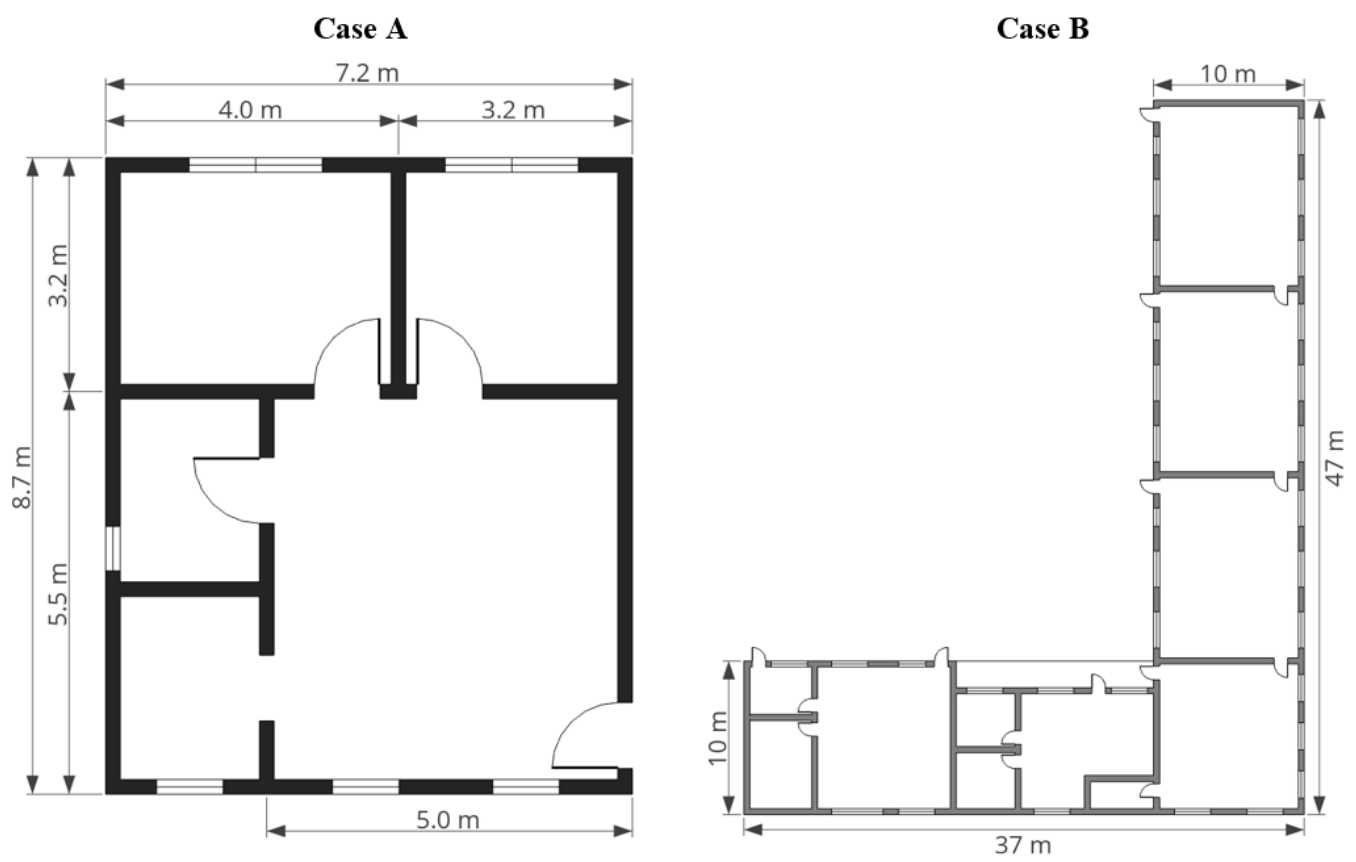

Figure 2. Floor plans of Case A: a granny flat with $63 \mathrm{~m}^{2}$ area; and Case B: a three-story school with $740 \mathrm{~m}^{2}$ per storey.

Table 3. Construction stages for conventional Case A and conventional Case B.

\begin{tabular}{|c|c|c|}
\hline Construction Stage & Conventional Case A & Conventional Case B \\
\hline Stage 1 & \multicolumn{2}{|c|}{$\begin{array}{c}\text { Step 1-Excavation } \\
\text { Step 2-Foundation } \\
\text { (Steel work, formwork, and concrete pouring) } \\
\text { Step 3-Backfill }\end{array}$} \\
\hline Stage 2 & $\begin{array}{l}\text { Slab on grade } \\
\text { (Steel work, formwork, and concrete } \\
\text { pouring) }\end{array}$ & $\begin{array}{c}\text { Step 1: Slab on grade } \\
\text { (Steel work, formwork, and concrete pouring) } \\
\text { Step 2: 1st level columns } \\
\text { (Steel work, formwork, and concrete pouring) } \\
\text { Step 3: Brickwork }\end{array}$ \\
\hline Stage 3 & $\begin{array}{c}\text { Walls } \\
\text { (Brickwork and Insulation) }\end{array}$ & $\begin{array}{c}\text { Step 1: 2nd level slab } \\
\text { (Steel work, formwork, and concrete pouring) } \\
\text { Step 2: 2nd level columns } \\
\text { (Steel work, formwork, and concrete pouring) } \\
\text { Step 3: Brickwork }\end{array}$ \\
\hline Stage 4 & $\begin{array}{l}\text { Step 1: Roof } \\
\text { (Frame, tiling, and insulation) } \\
\text { Step 2: Internal finishes }\end{array}$ & $\begin{array}{c}\text { Step 1: 3rd level slab } \\
\text { (Steel work, formwork, and concrete pouring) } \\
\text { Step 2: 3rd level columns } \\
\text { (Steel work, formwork, and concrete pouring) } \\
\text { Step 3: Brickwork } \\
\text { Step 4: Internal finishes }\end{array}$ \\
\hline
\end{tabular}

These case studies are considered appropriate for this study. First, the structures are identical between construction methods, only varying in material type and quantity, satisfying the first criteria. The volume of each material used is shown in Table 4 , with bulk densities also provided for conversion into weights. As noted above, the modular cases involve assembling fully serviced three dimensional units, satisfying the second criteria. Moreover, "projects similar to both case studies have been previously built in Australia using both construction methods" [18]. In addition, according to Hammad et al. [18], the modular and conventional structures in both case studies satisfy the Australian National Construction Code [44], and the Australian Standards for Concrete (AS3600), Steel (AS4100), 
Timber (AS1720.1), Masonry (AS3700), and Cold-formed Steel (AS4600). Therefore, the third criteria is considered satisfied. Finally, Hammad et al. [18] even suggests extending their framework to include waste estimation based on waste rates for each material, as the current study does not consider this vital environmental sustainability factor.

Table 4. Summed material quantity take-offs and bulk densities for case studies and construction methods.

\begin{tabular}{|c|c|c|c|c|c|}
\hline \multirow{2}{*}{ Material $^{1}$} & \multirow{2}{*}{ Bulk Density ${ }^{2}$} & \multicolumn{2}{|c|}{ Case A } & \multicolumn{2}{|c|}{ Case B } \\
\hline & & Conventional & Modular & Conventional & Modular \\
\hline $\begin{array}{l}\text { Concrete } \\
\text { - Poured concrete } \\
\text { - Screed } \\
\text { - } 10 \mathrm{~mm} \mathrm{CFC}\end{array}$ & $\begin{array}{l}2400 \mathrm{~kg} / \mathrm{m}^{3} \\
1900 \mathrm{~kg} / \mathrm{m}^{3} \\
1595 \mathrm{~kg} / \mathrm{m}^{3}\end{array}$ & $\begin{array}{c}37 \mathrm{~m}^{3} \\
- \\
-\end{array}$ & $\begin{array}{c}0.6 \mathrm{~m}^{3} \\
- \\
-\end{array}$ & $\begin{array}{l}1052 \mathrm{~m}^{3} \\
444 \mathrm{~m}^{3} \\
400 \mathrm{~m}^{3}\end{array}$ & $\begin{array}{c}25 \mathrm{~m}^{3} \\
- \\
400 \mathrm{~m}^{3}\end{array}$ \\
\hline $\begin{array}{l}\text { Steel } \\
\text { - Reinforcement } \\
\text { - Roof sheeting } \\
\text { - Roof flashing } \\
\text { - Battens } \\
\text { - C115 Purlin } \\
\text { - C181 Purlin } \\
\text { - } 110 \text { PFC } \\
\text { - } 140 \text { PFC } \\
\text { - } 200 \text { PFC } \\
\text { - } 380 \text { PFC } \\
\text { - } 400 \text { PFC } \\
\text { - } 75 \text { mm light steel } \\
\text { - } 90 \text { mm light steel } \\
\text { - Light steel studs } \\
\text { - } 75 \text { SHS }\end{array}$ & $\begin{array}{c}\mathrm{N} / \mathrm{A} \\
10 \mathrm{~kg} / \mathrm{m}^{2} \\
9 \mathrm{~kg} / \mathrm{m} \\
0.71 \mathrm{~kg} / \mathrm{m} \\
3.706 \mathrm{~kg} / \mathrm{m} \\
5.236 \mathrm{~kg} / \mathrm{m} \\
9.758 \mathrm{~kg} / \mathrm{m} \\
15.38 \mathrm{~kg} / \mathrm{m} \\
22.9 \mathrm{~kg} / \mathrm{m} \\
55.2 \mathrm{~kg} / \mathrm{m} \\
58.105 \mathrm{~kg} / \mathrm{m} \\
1.41 \mathrm{~kg} / \mathrm{m} \\
1.53 \mathrm{~kg} / \mathrm{m} \\
1.41 \mathrm{~kg} / \mathrm{m} \\
10.3 \mathrm{~kg} / \mathrm{m}\end{array}$ & $\begin{array}{c}0.83 \mathrm{t} \\
- \\
- \\
140 \mathrm{~m} \\
- \\
- \\
- \\
- \\
- \\
- \\
- \\
- \\
- \\
- \\
-\end{array}$ & $\begin{array}{c}0.04 \mathrm{t} \\
64 \mathrm{~m}^{2} \\
30 \mathrm{~m} \\
51 \mathrm{~m} \\
115 \mathrm{~m} \\
- \\
48 \mathrm{~m} \\
- \\
63 \mathrm{~m} \\
- \\
52 \mathrm{~m} \\
86 \mathrm{~m} \\
- \\
10.3 \mathrm{~m} \\
-\end{array}$ & $\begin{array}{c}72.35 \mathrm{t} \\
- \\
- \\
- \\
- \\
- \\
- \\
- \\
- \\
- \\
- \\
- \\
- \\
- \\
-\end{array}$ & $\begin{array}{c}0.642 \mathrm{t} \\
740 \mathrm{~m}^{2} \\
210 \mathrm{~m} \\
629 \mathrm{~m} \\
- \\
2673 \mathrm{~m} \\
- \\
288 \mathrm{~m} \\
144 \mathrm{~m} \\
810 \mathrm{~m} \\
52 \mathrm{~m} \\
- \\
842 \mathrm{~m} \\
- \\
528 \mathrm{~m}\end{array}$ \\
\hline $\begin{array}{l}\text { Masonry } \\
\text { - Bricks } \\
\text { - Other masonry }\end{array}$ & $\begin{array}{l}830.6 \mathrm{~kg} / \mathrm{m}^{3} \\
830.6 \mathrm{~kg} / \mathrm{m}^{3}\end{array}$ & $\begin{array}{c}25 \mathrm{~m}^{3} \\
-\end{array}$ & - & $\begin{array}{l}220 \mathrm{~m}^{3} \\
270 \mathrm{~m}^{3}\end{array}$ & - \\
\hline $\begin{array}{l}\text { Timber } \\
\text { - Formwork } \\
\text { - Internal walls } \\
\text { - Joists }\end{array}$ & $\begin{array}{l}10.7 \mathrm{~kg} / \mathrm{m}^{2} \\
7.59 \mathrm{~kg} / \mathrm{m}^{2} \\
5.445 \mathrm{~kg} / \mathrm{m}\end{array}$ & $\begin{array}{l}9.5 \mathrm{~m}^{2} \\
96 \mathrm{~m}^{2} \\
163 \mathrm{~m}\end{array}$ & $\begin{array}{c}1.5 \mathrm{~m}^{2} \\
- \\
-\end{array}$ & $\begin{array}{c}3625 \mathrm{~m}^{2} \\
- \\
-\end{array}$ & $\begin{array}{c}87 \mathrm{~m}^{2} \\
- \\
-\end{array}$ \\
\hline $\begin{array}{l}\text { Insulation } \\
\text { - Type } 1 \\
\text { - Wall insulation } \\
\text { - Roof insulation } \\
\text { - Vapour barrier } \\
\text { - } 6 \text { mm PVC lining }\end{array}$ & $\begin{array}{c}1.44 \mathrm{~kg} / \mathrm{m}^{2} \\
25 \mathrm{~kg} / \mathrm{m}^{3} \\
20.023 \mathrm{~kg} / \mathrm{m}^{3} \\
0.184 \mathrm{~kg} / \mathrm{m}^{2} \\
8.28 \mathrm{~kg} / \mathrm{m}^{2}\end{array}$ & $\begin{array}{c}96 \mathrm{~m}^{2} \\
- \\
19.5 \mathrm{~m}^{3} \\
96 \mathrm{~m}^{2} \\
-\end{array}$ & $\begin{array}{c}- \\
- \\
33 \mathrm{~m}^{3} \\
- \\
72 \mathrm{~m}^{2}\end{array}$ & $\begin{array}{c}- \\
990 \mathrm{~m}^{3} \\
140 \mathrm{~m}^{3}- \\
-\end{array}$ & $\begin{array}{c}- \\
- \\
555 \mathrm{~m}^{3} \\
- \\
-\end{array}$ \\
\hline $\begin{array}{l}\text { Other } \\
\text { - Bitumen } \\
\text { - Roof tiles } \\
\text { - Plasterboard }\end{array}$ & $\begin{array}{c}20.833 \mathrm{~kg} / \mathrm{m}^{2} \\
57 \mathrm{~kg} / \mathrm{m}^{2} \\
8.3 \mathrm{~kg} / \mathrm{m}^{2}\end{array}$ & $\begin{array}{l}13 \mathrm{~m}^{2} \\
65 \mathrm{~m}^{2} \\
96 \mathrm{~m}^{2}\end{array}$ & $\begin{array}{c}6 \mathrm{~m}^{2} \\
- \\
96 \mathrm{~m}^{2}\end{array}$ & $\begin{array}{c}740 \mathrm{~m}^{2} \\
- \\
-\end{array}$ & $\begin{array}{c}93 \mathrm{~m}^{2} \\
- \\
-\end{array}$ \\
\hline
\end{tabular}

${ }^{1}$ PFC: Parallel flange channel; CFC: Compressed fibre cement; SHS: Square hollow section; PVC: Polyvinyl chloride, ${ }^{2}$ As obtained from [40,42,43,45-55]; AS 3600: 2018; AS 1366.3: 1992; ACI 347R-14.

\subsection{Data Analysis}

This study applied an analysis of existing statistics (a method of secondary data analysis) to analyse the data detailed in previous sections, due to its strength in comparative work and emerging validity $[56,57]$. A quantitative approach was used to apply the waste rates for both modular and conventional construction techniques to Cases A and B. For conventional construction, the waste rates from all references were applied to both cases, providing estimations based on both material loss rates and GFA. A simple average was then taken to determine the overall waste generation for conventional construction. It 
is important to note that the waste rates from any individual reference, or selection of references, could have been used and will still be considered a valid analysis. However, averaging waste rates in this way allows for a moderate approximation, with reduced probability of extremity $[58,59]$. For modular construction, a $5 \%$ waste rate is applied to Case A, and a 3\% waste rate is applied to Case B, as outlined by Kim [27]. This reflects the industry consensus that smaller structures produce higher waste per capita than larger structures due to the lower repeatability of structural elements.

\section{Result Analysis}

This section provides an analysis of the research results. The waste generation estimations for conventional construction and modular construction are first displayed separately and are then compared together for both Case A and Case B.

\subsection{Conventional Waste Generation}

Tables A1 and A2 (Appendix A) summarise the waste generation by weight for Case A and Case $B$, respectively, when waste rates from all references are applied. A large range for most materials and categories can be seen. This is not surprising, as waste rate estimations for conventional construction vary greatly based on the nature of the structure, the type of structure, geographical location, and many other factors.

Tables 5 and 6 show a singular waste generation estimation for Case A and Case B, respectively. A comparison of quantity take off is also included to produce a material loss rate for each category and material, as defined in Equation (1). To determine a single waste estimation for the cases, a simple average was taken across all references. The upper and lower bounds from Bakshan et al. [40] were not considered in this calculation, as the typical value was provided. While it is equally valid to select any individual, or a group of individual references, this approach allows for a moderate estimate considering a wide range of case studies. Some references had waste rates for a material category, but not for specific materials within that category. In these cases, waste rates were averaged both by category (considering all references) and also by specific materials where data were available. Consequently, several categories of materials have waste weights greater than the summation of their parts. This additional, unaccounted-for material can be attributed to other waste within the category that is not specified within this analysis.

Table 5. Average waste generation for Case A conventional construction.

\begin{tabular}{|c|c|c|c|c|}
\hline Category/Material & Quantity Take off (kg) & Average Waste (kg) & Total Material (kg) & $\operatorname{MLR}^{1}(\%)$ \\
\hline $\begin{array}{l}\text { Concrete (poured } \\
\text { concrete) }\end{array}$ & $88,800.00$ & 1674.35 & $90,474.83$ & 1.89 \\
\hline Steel & 929.40 & 66.68 & 996.08 & 7.17 \\
\hline - $\quad$ Reinforcement & 830.00 & 49.70 & 879.70 & 5.99 \\
\hline - $\quad$ Battens & 99.40 & 5.95 & 105.35 & 5.99 \\
\hline Bitumen & 270.83 & 94.50 & 365.33 & 34.89 \\
\hline Masonry (brick) & $20,765.00$ & 1445.11 & $22,210.11$ & 6.96 \\
\hline $\begin{array}{l}\text { Timber (excluding } \\
\text { formwork) }\end{array}$ & 1717.83 & 226.04 & 1943.87 & 13.99 \\
\hline - $\quad$ Internal walls & 728.64 & 66.60 & 795.24 & 9.14 \\
\hline - $\quad$ Joists & 887.54 & 81.12 & 968.66 & 9.14 \\
\hline Formwork & 101.65 & 50.21 & 151.86 & 49.40 \\
\hline Tiles (roof tiles) & 3705.00 & 132.96 & 3837.96 & 3.59 \\
\hline Plasterboard & 796.80 & 153.85 & 950.65 & 19.31 \\
\hline
\end{tabular}


Table 5. Cont.

\begin{tabular}{lcccc}
\hline \multicolumn{1}{c}{ Category/Material } & Quantity Take off (kg) & Average Waste (kg) & Total Material (kg) & MLR $\mathbf{1}(\mathbf{\%})$ \\
\hline Insulation & 546.35 & 40.95 & 587.30 & 7.50 \\
$-\quad$ Type 1 & 138.24 & No data & N/A & N/A \\
$-\quad$ Roof insulation & 390.45 & No data & N/A & N/A \\
$-\quad$ Vapour barrier & 17.66 & No data & N/A & N/A \\
\hline
\end{tabular}

${ }^{1}$ MLR: Material Loss Rate as defined by Equation (1).

Table 6. Average waste generation for Case B conventional construction.

\begin{tabular}{lcccc}
\hline \multicolumn{1}{c}{ Category/Material } & Quantity Take off (kg) & Average Waste (kg) & Total Material (kg) & MLR $\mathbf{~}^{\mathbf{\%})}$ \\
\hline Concrete (excluding & $3,368,400$ & 61,143 & $4,067,543$ & 1.82 \\
CFC) & $2,524,800$ & 54,889 & $2,579,689$ & 2.17 \\
$-\quad$ Poured concrete & 843,600 & 18,340 & 861,940 & 2.17 \\
$-\quad$ Screed & 638,000 & 29,806 & 667,806 & 4.67 \\
\hline 10 mm CFC & 72,350 & 5887 & 78,237 & 8.14 \\
\hline Steel (Reinforcement) & 15,416 & 8103 & 23,519 & 52.56 \\
\hline Bitumen & 406,994 & 45,800 & 452,794 & 11.25 \\
\hline Masonry & 182,732 & 9054 & 191,786 & 4.96 \\
$-\quad$ Brick & 224,262 & 11,112 & 235,374 & 4.96 \\
$-\quad$ Other & 38,788 & 19,160 & 57,948 & 49.40 \\
\hline Formwork & 27,553 & 1776 & 29,329 & 6.45 \\
\hline Insulation & 24,750 & No data & N/A & N/A \\
$-\quad$ Wall insulation & 2803 & No data & N/A & N/A \\
\hline
\end{tabular}

${ }^{1}$ MLR: Material Loss Rate as defined by Equation (1).

\subsection{Modular Waste Generation}

Tables 7 and 8 show a singular waste generation for Case A and Case B, respectively, with waste rates applied from Kim [27] as outlined in previous sections. Some materials, including poured concrete, steel reinforcement, bitumen, and formwork, were used in site preparation and foundation work, and were constructed conventionally. Therefore, appropriate material loss rates from Tables 5 and 6 were used for these materials.

Additional material was also added to both modular Case A and Case B to reflect external wall material. Applying bulk densities to external wall elements in Table 4 would imply that the external walls in Case A and Case B weighed just $121.26 \mathrm{~kg}$ and $1288 \mathrm{~kg}$, respectively. This is clearly not the case, so an adjustment was made. As the weight distribution of a typical steel modular unit is comprised of $25 \%$ wall material and $32 \%$ steel skeleton [60], and the weight of the steel skeleton is $5373.26 \mathrm{~kg}$ and $74,895 \mathrm{~kg}$ in Case A and Case B, respectively, the weight of the external walls is set to $4197.86 \mathrm{~kg}$ and $58,512 \mathrm{~kg}$ in Case A and Case B, respectively. An additional $438 \mathrm{~kg}$ is added for studs in Case B as outlined by Hammad et al. [18]

\subsection{Waste Comparison}

The total wastes for conventional and modular methods in both cases cannot easily be compared as they are comprised of vastly different materials. However, total waste weights can be compared between structure elements (foundation, flooring, external walls, columns, internal walls, beam systems, stairs, and roof), as well as for the overall structure. Table 9 shows that, for both cases, the modular method produces less waste both overall and for every structure element. Overall, Case A had an 81.3\% reduction in waste, and 
Case B had an $83.2 \%$ reduction in waste. This result is to be expected, as prefabrication fundamentally changes construction into a highly controlled factory environment.

Table 7. Average waste generation for Case A modular construction.

\begin{tabular}{|c|c|c|c|c|}
\hline Category/Material & Quantity Take off (kg) & Average Waste (kg) & Total Material (kg) & $\operatorname{MLR}^{1}(\%)$ \\
\hline $\begin{array}{l}\text { Concrete (poured } \\
\text { concrete) }{ }^{2}\end{array}$ & 1440.00 & 27.22 & 1467.22 & 1.89 \\
\hline Steel & 6344.94 & 318.12 & 6663.06 & 5.01 \\
\hline - $\quad$ Reinforcement $^{2}$ & 40.00 & 2.87 & 42.87 & 7.17 \\
\hline Battens & 36.21 & 1.81 & 38.02 & 5 \\
\hline Roof sheeting & 640.00 & 32.00 & 672.00 & 5 \\
\hline C115 Purlin & 426.19 & 21.31 & 447.50 & 5 \\
\hline 110 PFC & 468.38 & 23.42 & 491.80 & 5 \\
\hline 200 PFC & 1442.70 & 72.14 & 1514.84 & 5 \\
\hline 400 PFC & 3021.46 & 151.07 & 3172.53 & 5 \\
\hline Roof flashing & 270.00 & 13.50 & 283.5 & 5 \\
\hline Light steel & 4212.38 & 210.62 & 4423.00 & 5 \\
\hline - $\quad 75 \mathrm{~mm}$ (walls) & 4197.86 & 209.89 & 4407.75 & 5 \\
\hline Studs & 14.52 & 0.73 & 15.25 & 5 \\
\hline Bitumen $^{2}$ & 125.00 & 43.61 & 168.61 & 34.89 \\
\hline Formwork $^{2}$ & 16.05 & 7.93 & 23.98 & 49.40 \\
\hline Plasterboard & 796.80 & 39.84 & 836.64 & 5 \\
\hline Insulation & 1256.92 & 62.85 & 1319.77 & 5 \\
\hline - $\quad$ Roof insulation & 660.76 & 33.04 & 693.80 & 5 \\
\hline $6 \mathrm{~mm}$ PVC lining & 596.16 & 29.81 & 625.97 & 5 \\
\hline
\end{tabular}

${ }^{1}$ MLR: Material Loss Rate as defined by Equation $(1) ;{ }^{2}$ Materials constructed conventionally.

Table 8. Average waste generation for Case B modular construction.

\begin{tabular}{|c|c|c|c|c|c|}
\hline & Category/Material & Quantity Take off (kg) & Average Waste (kg) & Total Material (kg) & $\operatorname{MLR}^{1}(\%)$ \\
\hline \multicolumn{2}{|c|}{ Concrete } & 698,000 & 20,232 & 718,232 & 2.90 \\
\hline- & Poured concrete $^{2}$ & 60,000 & 1092 & 61,092 & 1.82 \\
\hline- & $10 \mathrm{~mm}$ CFC & 638,000 & 19,140 & 657,140 & 3 \\
\hline \multicolumn{2}{|c|}{ Steel } & 85,318 & 2593 & 87,911 & 3.04 \\
\hline- & Reinforcement $^{2}$ & 642 & 52 & 694 & 8.14 \\
\hline- & Battens & 491 & 15 & 506 & 3 \\
\hline- & Roof Sheeting & 7400 & 222 & 7622 & 3 \\
\hline- & C181 Purlin & 13,996 & 420 & 14,416 & 3 \\
\hline- & 140 PFC & 4429 & 133 & 4562 & 3 \\
\hline- & 200 PFC & 3298 & 99 & 3397 & 3 \\
\hline- & 380 PFC & 44,712 & 1341 & 46,053 & 3 \\
\hline- & 400 PFC & 3021 & 91 & 3112 & 3 \\
\hline- & 75 SHS & 5438 & 163 & 5602 & 3 \\
\hline- & Roof flashing & 1890 & 57 & 1947 & 3 \\
\hline \multicolumn{2}{|c|}{ Light steel } & 58,949 & 1768 & 60,718 & 3 \\
\hline- & $90 \mathrm{~mm}$ external walls & 58,512 & 1755 & 60,267 & 3 \\
\hline- & $90 \mathrm{~mm}$ internal walls & 438 & 13 & 451 & 3 \\
\hline
\end{tabular}


Table 8. Cont.

\begin{tabular}{lccccc}
\hline \multicolumn{1}{c}{ Category/Material } & Quantity Take off (kg) & Average Waste (kg) & Total Material (kg) & MLR $\mathbf{~}^{\mathbf{1} \%)}$ \\
\hline Bitumen $^{2}$ & 1937 & 1018 & 2956 & 52.56 \\
\hline Formwork $^{2}$ & 931 & 460 & 1391 & 49.40 \\
\hline Insulation (roof) & 11,113 & 333 & 11,446 & 3 \\
\hline
\end{tabular}

Table 9. Comparison of waste generation by conventional and modular construction for Case A and Case B.

\begin{tabular}{|c|c|c|c|c|c|c|}
\hline \multirow{2}{*}{$\begin{array}{l}\text { Structure } \\
\text { Element }\end{array}$} & \multicolumn{3}{|c|}{ Case A } & \multicolumn{3}{|c|}{ Case B } \\
\hline & $\begin{array}{l}\text { Conventional } \\
\text { Waste (kg) }\end{array}$ & Modular Waste (kg) & $\begin{array}{c}\% \\
\text { Change }\end{array}$ & $\begin{array}{c}\text { Conventional } \\
\text { Waste (kg) }\end{array}$ & Modular Waste (kg) & $\begin{array}{c}\% \\
\text { Change }\end{array}$ \\
\hline Foundation & 161 & 82 & -49.1 & 11,439 & 2622 & -77.1 \\
\hline $\begin{array}{l}\text { Flooring } \\
\text { structure (plus } \\
\text { chassis for } \\
\text { modular) }\end{array}$ & 1712 & 245 & -85.7 & 38,994 & 1852 & -95.3 \\
\hline External walls & 1445 & 233 & -83.9 & 21,783 & 1822 & -91.6 \\
\hline Columns & $\mathrm{N} / \mathrm{A}$ & $\mathrm{N} / \mathrm{A}$ & $\mathrm{N} / \mathrm{A}$ & 10,838 & 96 & -99.1 \\
\hline Internal walls & 232 & 70 & -69.8 & 29,795 & 19,153 & -35.7 \\
\hline Beam system & $\mathrm{N} / \mathrm{A}$ & $\mathrm{N} / \mathrm{A}$ & $\mathrm{N} / \mathrm{A}$ & 8211 & 232 & -97.17 \\
\hline Stairs & $\mathrm{N} / \mathrm{A}$ & $\mathrm{N} / \mathrm{A}$ & $\mathrm{N} / \mathrm{A}$ & 6520 & - & -100 \\
\hline Roof & 248 & 82 & -66.9 & 30,049 & 627 & -97.9 \\
\hline Sum & 3798 & 712 & -81.3 & 157,629 & 26,404 & -83.2 \\
\hline
\end{tabular}

\section{Discussion}

As noted above, modular construction has the potential to significantly reduce waste generation, in the case studies considered. By weight, an $83.2 \%$ waste reduction is possible in large structures, with a comparable $81.3 \%$ reduction in smaller structures (see Table 9). These waste reductions are more clearly shown in Figures 3 and 4. In general, this aligns with prior research that asserts that prefabrication will reduce waste. The perception in the industry of reduced waste in prefabrication $[30,31]$ has been verified. Qualitative comparisons asserting that prefabrication reduces waste [20-22] have also been verified. For quantitative comparisons, the results show greater waste reductions than most previous studies. Quale et al. [23], Jaillon et al. [32], Kim [27], Jaillon and Poon [31], and Hosseini et al. [38] showed waste reductions of $20.1 \%, 52 \%, 60 \%, 65 \%$, and $92 \%$, respectively. However, as discussed above, these comparisons are related to partially prefabricated structures [31,32], studies where waste reductions are used for other purposes and are therefore not valid comparisons [23], are comparisons with numerous assumptions and simplifications [27], or are comparisons in relation to certain structure components only [38]. When comparing them to structures with significant prefabrication [31,32], the results imply that increasing the prefabrication rate until modular structures are achieved will continue to decrease the waste generation. An inversely proportional relationship between the level of prefabrication and waste generation can therefore be inferred. This is reinforced by Tam et al. [33], who find that waste for a structure component is reduced by $35-100 \%$ when that component is partially or fully replaced with prefabrication. In addition, Hosseini et al. [38] assert a 92\% reduction in reinforcing rebar waste when lean practices (i.e., prefabrication) are used. This high reduction could potentially be extrapolated to other structure components, and it could be assumed that modular construction, which achieves the highest level of prefabrication, would result in the largest possible waste reduction, a conclusion shared by this paper. However, based on the current results and past literature, this cannot be known for certain. It is possible that an "optimal level" of prefabrication exists below modular construction such that waste generation is minimised. This optimal level of prefabrication may also be different for different factors, 
such as construction cost, transport cost, equipment cost, logistic cost, project time, labour requirements, hazard potential and safety incidents, greenhouse gas emissions, electricity usage, embodied energy, etc. Not only this, but these optimal levels would be regional and project-dependent, and could change based on the nature of the project, the firm(s) carrying out the work, manufacturing availability, government involvement, and various other factors. In the most basic terms, these results demonstrate that implementing modular construction has the potential to significantly reduce waste generation in construction.

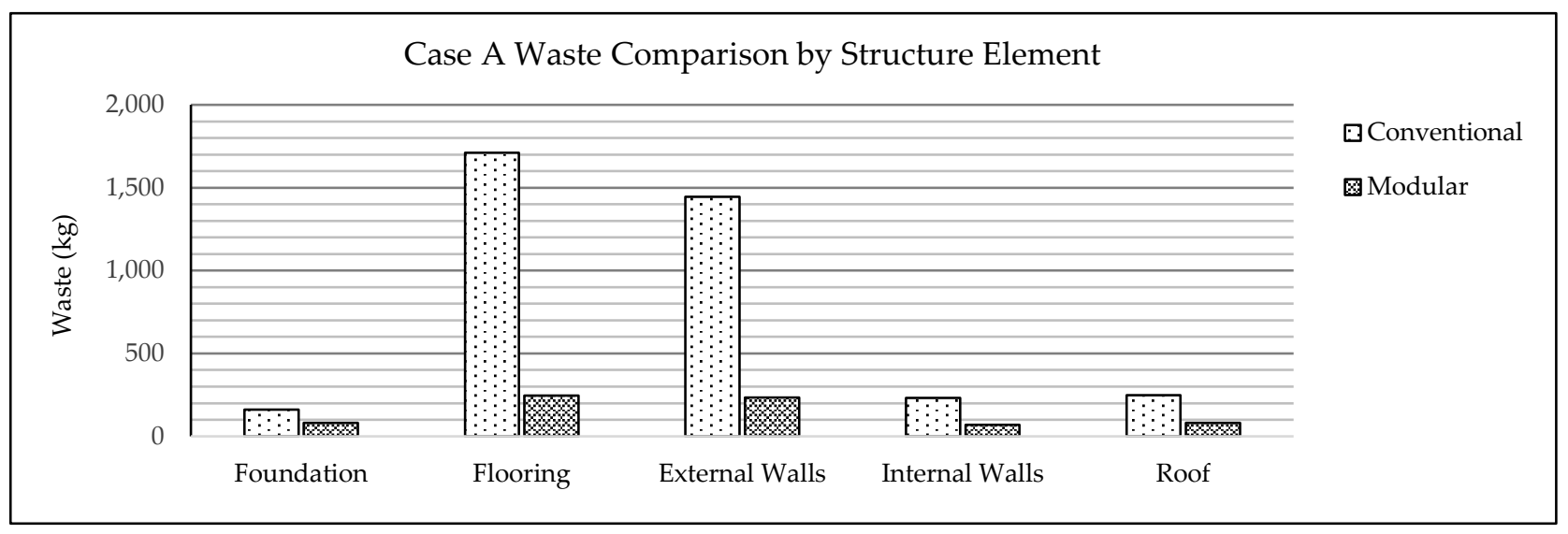

Figure 3. Case A waste comparison by structure element.

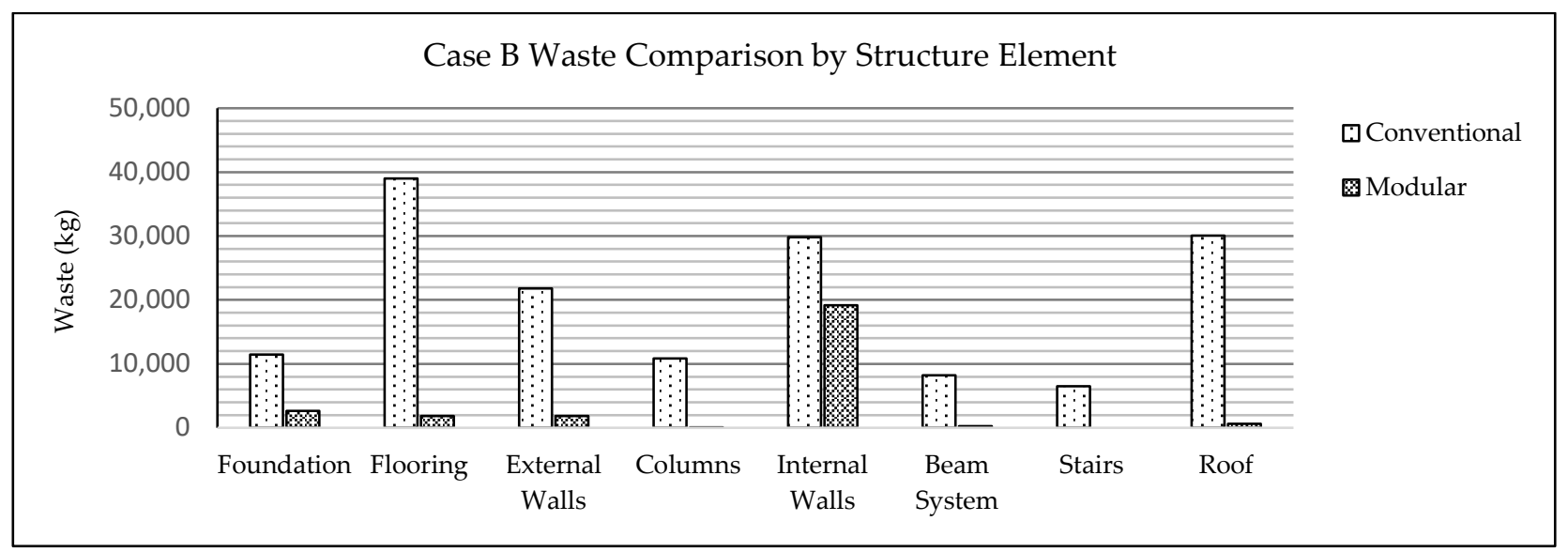

Figure 4. Case B waste comparison by structure element.

\subsection{Waste and Weight}

An issue with the comparison above is that the materials used between the modular and conventional techniques are vastly different. This results in a significant difference in overall weights of the structure, depending on the construction method selected. Namely, the modular structures weigh $87.9 \%$ and $81.3 \%$ less than the conventional structures in Case A and Case B, respectively. This contradicts previous literature, which asserts that modular structures can have up to $25 \%$ increased material requirements due to the increased need for structural integrity in each module $[4,27,61]$. However, these studies only compared structure weights when identical materials are used in both construction methods. Kim [27], for instance, estimates that modular homes require $9.9 \%$ more material when timber modules are used compared to conventional timber homes. When different materials are used, such as in these cases, the weight difference can be significant. Aye et al. [21] demonstrate how material consumption is reduced by $78 \%$ when switching from conventional reinforced concrete construction to a prefabricated steel structure, a result that is similar to this study, which compares conventional masonry and reinforced 
concrete structures to prefabricated steel structures. When considering waste, this significant difference in total structure weight must be put into context. Table 10 compares waste generation as a percentage of total material (i.e., waste generated per $100 \mathrm{~kg}$ of total material). When considering waste as a percentage of total material, modular construction produces around $13.1 \%$ less weight in Case B. However, modular construction produces around $52.7 \%$ more waste in Case A, even though less waste is produced overall. This is largely due to the $5 \%$ waste rate assumption for modular Case A. The decision to apply this waste rate was to reflect the higher waste generation often seen in smaller structures due to a lack of repeatability. However, modular construction is a highly controlled, repetitive process, even at small scales. A 3\% waste rate, like that used in modular Case B, may have been more appropriate. When a 3\% waste rate is applied to modular Case A, total waste generation reduces to $460 \mathrm{~kg}$, implying $3.14 \%$ waste as a percentage of total material. This is highly comparable to the conventional waste percentage of $3.13 \%$ of total material. In addition, waste in conventional Case A is likely underestimated due to the low material loss rate of concrete, which is averaged to $1.89 \%$. If a more typical concrete waste rate of $5 \%$ is used, as suggested by Treloar et al. [43], then total waste in conventional Case A would increase to $6561 \mathrm{~kg}$. This, a more realistic estimate, would imply $5.29 \%$ waste as a percentage of total material for conventional Case $\mathrm{A}$, a value higher than both the reduced and current estimation for waste percentage in modular Case A. Moreover, a 3\% waste rate assumption for all modular activities is still likely an overestimation. Recent literature asserts that prefabrication can reduce waste to almost zero due to the elimination of offcuts $[19,20]$. This result allows decision makers and stakeholders to make more informed decisions considering construction waste. At large scales, waste percentage will most likely be reduced. At smaller scales, care is needed to minimise modular waste as much as possible in order to reduce its waste percentage below conventional construction.

Table 10. Comparison of modular and conventional waste generation per $100 \mathrm{~kg}$ of total material.

\begin{tabular}{cccccc}
\hline & $\begin{array}{c}\text { Construction } \\
\text { Method }\end{array}$ & Quantity Take off (kg) & Total Waste (kg) & Total Material (kg) & $\begin{array}{c}\text { Waste Per 100 kg } \\
\text { Total Material (kg) }\end{array}$ \\
\hline \multirow{2}{*}{ Case A } & Conventional & 117,531 & 3798 & 121,329 & 3.13 \\
& Modular & 14,192 & 712 & 14,904 & 4.78 \\
\hline \multirow{2}{*}{ Case B } & Conventional & $4,567,501$ & 157,629 & $4,725,130$ & 3.34 \\
& Modular & 856,248 & 26,404 & 882,652 & 2.99 \\
\hline
\end{tabular}

\subsection{Cost of Weight}

The results above also imply cost savings from an overall reduced weight of waste. Table 11 shows that, in Case B, modular construction reduces the cost of weight by around $47.9 \%$. However, in Case A, using conventional construction reduces the cost of waste by around $58.5 \%$. This was not expected, considering that overall waste weight is reduced significantly in the modular cases. However, the cost of materials in the modular cases are generally higher than those in the conventional cases. In Case B, the reduced material needs in the modular case are sufficient to overcome the increased material costs, and therefore a reduction in cost of waste is observed. Conversely, in modular Case A, where waste as a percentage of total material is higher in the conventional case (see Table 10), the reduced material weights are not sufficient to overcome increases in material costs, and therefore an increase in cost of waste is observed. This increase in cost of waste for modular Case $\mathrm{A}$ is not overcome by reducing the waste rate of modular construction to $3 \%$ and increasing the material loss rate of conventional Case A concrete to $5 \%$, as was done above. In fact, when a $3 \%$ waste rate is implemented for modular construction, the cost of waste in modular Case A is reduced to 3383.99 AUD, and, when a 5\% waste rate for conventional Case A concrete is used, cost of waste in conventional Case A is increased to 2603.24 AUD. Cost of waste in conventional Case A would still be $23.07 \%$ lower than modular Case A. This implies that, due to increased material costs in modular construction, reductions in 
overall waste are only economically beneficial in larger structures. However, modular construction has the potential to reduce its material loss rate far below 3\%. In fact, when a material loss rate of $2 \%$ is applied, cost of waste in modular Case A reduces to 2283.34 AUD, a cost comparable to the current estimation for conventional Case A. This MLR can be easily achieved, and reduced even further, in the controlled factory environment that prefabrication enables, as discussed above. Utilising modular construction therefore allows for potential economic benefits at any scale.

Table 11. Cost of waste for case studies and construction methods.

\begin{tabular}{|c|c|c|c|c|c|}
\hline \multirow{2}{*}{ Material } & \multirow{2}{*}{ Cost $/$ kg $^{1}$ (AUD) } & \multicolumn{2}{|c|}{ Cost of Waste, Case A (AUD) } & \multicolumn{2}{|c|}{ Cost of Waste, Case B (AUD) } \\
\hline & & Conventional & Modular & Conventional & Modular \\
\hline \multicolumn{6}{|l|}{ Concrete } \\
\hline - Poured Concrete & 0.10 & 171.62 & 2.79 & 5626.12 & 111.93 \\
\hline - Screed & 1.85 & - & - & $33,929.00$ & - \\
\hline$-10 \mathrm{~mm} \mathrm{CFC}$ & 3.78 & - & - & $112,664.81$ & $72,348.00$ \\
\hline \multicolumn{6}{|l|}{ Steel } \\
\hline - Reinforcement & 1.52 & 75.30 & 4.35 & 8918.81 & 78.78 \\
\hline - Roof sheeting & 7.70 & - & 246.24 & - & 1708.29 \\
\hline - Roof flashing & 0.61 & 37.96 & 8.30 & - & 35.02 \\
\hline - Battens & 6.38 & - & 11.55 & - & 95.70 \\
\hline - C115 Purlin & 2.14 & - & 45.60 & - & - \\
\hline - C181 Purlin & 2.18 & - & - & - & 916.84 \\
\hline - 110 PFC & 2.70 & - & 63.19 & - & - \\
\hline - 140 PFC & 2.51 & - & - & - & 334.06 \\
\hline - 200 PFC & 2.76 & - & 199.13 & - & 273.27 \\
\hline - 380 PFC & 2.48 & - & - & - & 3327.72 \\
\hline - 400 PFC & 2.50 & - & 377.43 & - & 227.36 \\
\hline - $90 \mathrm{~mm}$ light steel & 8.49 & - & - & - & 110.37 \\
\hline - Light steel studs & 8.34 & - & 6.09 & - & - \\
\hline - 75 SHS & 2.52 & - & - & - & 411.46 \\
\hline - Walls & 21.52 & & 4516.08 & & $37,761.27$ \\
\hline \multicolumn{6}{|l|}{ Masonry } \\
\hline - Bricks & 0.59 & 856.23 & - & 5364.50 & - \\
\hline - Other Masonry & 0.59 & - & - & 6583.86 & - \\
\hline \multicolumn{6}{|l|}{ Timber } \\
\hline - Formwork & 2.48 & 124.45 & 19.65 & $47,488.15$ & 1140.11 \\
\hline - Internal Walls & 7.14 & 475.33 & - & - & - \\
\hline - Joists & 3.32 & 269.66 & - & - & - \\
\hline \multicolumn{6}{|l|}{ Other } \\
\hline - Bitumen & 1.27 & 119.75 & 55.26 & $10,268.29$ & 1290.03 \\
\hline - Roof tiles & 0.56 & 75.11 & - & - & - \\
\hline - Plasterboard & 0.74 & 114.37 & 29.62 & - & - \\
\hline \multicolumn{2}{|c|}{ Sum } & 2319.76 & 5585.27 & $230,843.53$ & $120,170.21$ \\
\hline
\end{tabular}

\footnotetext{
${ }^{1}$ Obtained from inquiries to material suppliers. Prices in AUD as of June 2021.
}

An important factor to note is that costs were estimated based on the amount of waste for each material, rather than for each category. Insulation waste was not included in the analysis as only categorical data were available. When considering a structure, the cost of insulation is considered insignificant, and it is therefore deemed appropriate to exclude. 


\section{Conclusions}

This paper compares the waste generated from conventional and modular construction techniques. A significant reduction in waste weight is determined $(81.3 \%$ and $83.2 \%$ in small and large structures, respectively) when modular construction is used. These results act as an extension of prior research, which assert that prefabrication reduces waste by $20-65 \%$, depending on the level of prefabrication. This reduces the research gap in comparing fully modular structures to conventional structures, assisting policy makers and stakeholders in making more informed decisions, while also providing thoroughly researched waste rates as a foundation for future research. While it is recommended to use the average material loss rates to reduce the likelihood of extremities, any individual, or group of individual's, waste rates from the gathered sources can be used to create valid waste estimations for future cases. It is also likely that the results will vary based on the case studies used. However, the framework allows for waste and costing estimations for estimations to be made in any relevant case.

The use of secondary data, based in a detailed literature review, for the generation of the waste rates is a major limitation of this framework. While generally applicable at an international level, secondary data often perform poorly at a local or regional level, even when the secondary data are gathered only from the area of interest. Waste rates often vary significantly based on numerous factors, including the nature of the project, the economic environment, and the firm(s) carrying out the work, etc. Therefore, further investigation into the waste rates themselves is recommended. Primary data collection in an area of interest can increase the accuracy and validity of the waste estimation. It is recommended to either (1) compare quantity take offs to total ordered materials and consider the difference as waste, or (2) measure on-site waste directly through observation, categorisation and weightings. The second approach would be highly labour- and resource-intensive, and would not measure excess material incorporated into a structure unless careful observations are made. A detailed review of material quantities across numerous case studies in an area of interest is therefore considered more appropriate and recommended as further research to improve the validity of the waste rates. As waste varies significantly, even at the local level, it is also recommended to categorise waste rates for materials by their project properties, such as size (GFA, number of stories, height, etc.), structure type (residential, commercial, industrial), main structural component (steel, masonry, reinforced concrete, timber, etc), characteristics of the construction company, or other factors.

In addition, the optimal level of prefabrication for waste minimisation is unknown. While implied to be optimal at the modular level, further research must be conducted towards relating prefabrication level to waste reduction, and determining the relationship between these variables. The optimal level of prefabrication for other variables can also be considered, such as various costs, project time, labour requirements, etc. Overall, this paper succeeds in determining the waste reductions in fully modular structures when compared to conventional structures, while also determining associated costs.

Author Contributions: Conceptualization, L.L., K.B. and X.S.; methodology, L.L.; validation, L.L; K.B. and X.S.; formal analysis, L.L.; investigation, L.L.; writing—original draft preparation, L.L.; writing-review and editing, L.L., K.B., X.S. and B.L.; visualization, L.L.; supervision, K.B. and X.S. All authors have read and agreed to the published version of the manuscript.

Funding: This research received no external funding.

Data Availability Statement: Data sharing not applicable.

Conflicts of Interest: The authors declare no conflict of interest. 


\section{Appendix A}

Table A1. Waste generation for Case A conventional construction based on the literature (kg).

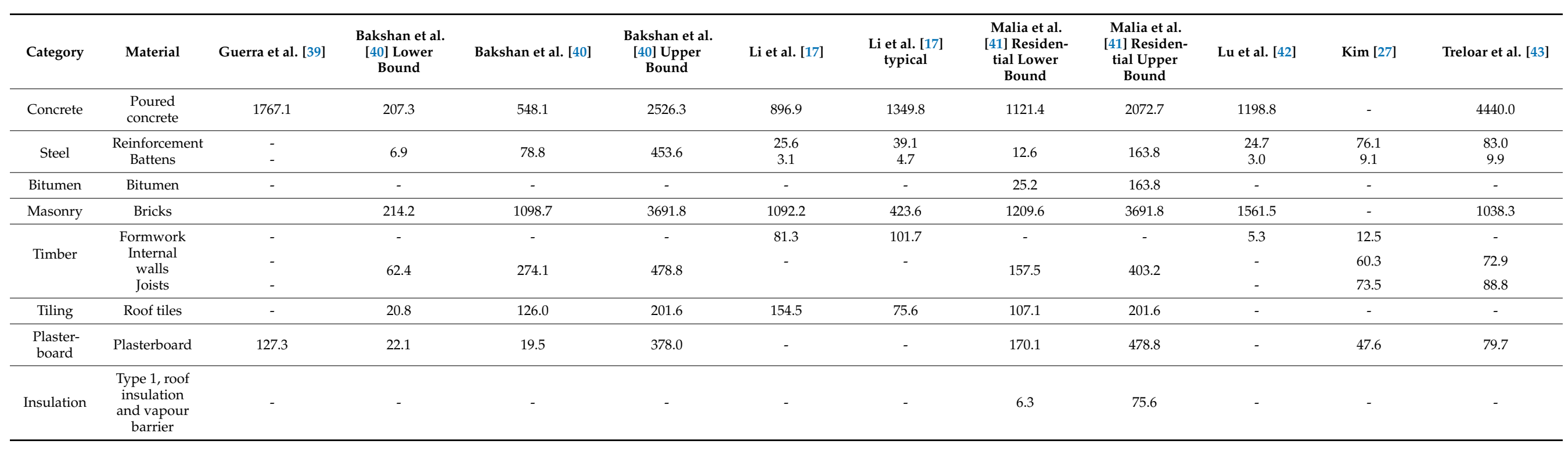

Table A2. Waste generation for Case B conventional construction based on literature (kg).

\begin{tabular}{|c|c|c|c|c|c|c|c|c|c|c|c|c|}
\hline Category & Material & Guerra et al. [39] & $\begin{array}{l}\text { Bakshan et al. } \\
\text { [40] Lower } \\
\text { Bound }\end{array}$ & Bakshan et al. [40] & $\begin{array}{l}\text { Bakshan et al. } \\
\text { [40] Upper } \\
\text { Bound }\end{array}$ & Li et al. [17] & $\begin{array}{c}\text { Li et al. [17] } \\
\text { Typical }\end{array}$ & $\begin{array}{l}\text { Malia et al. } \\
\text { [41] Residen- } \\
\text { tial Lower } \\
\text { Bound }\end{array}$ & $\begin{array}{l}\text { Malia et al. } \\
\text { [41] Residen- } \\
\text { tial Upper } \\
\text { Bound }\end{array}$ & Lu et al. [42] & $\operatorname{Kim}[27]$ & Treloar et al. [43] \\
\hline \multirow[b]{2}{*}{ Concrete } & $\begin{array}{l}\text { Poured } \\
\text { concrete }\end{array}$ & 50,244 & \multirow{2}{*}{7304} & \multirow{2}{*}{19,314} & \multirow{2}{*}{89,022} & \multirow{2}{*}{$\begin{array}{c}25,500 \\
8520\end{array}$} & 38,377 & \multirow{2}{*}{40,626} & 89,022 & \multirow{2}{*}{$\begin{array}{l}34,085 \\
11,389\end{array}$} & \multirow[b]{2}{*}{38,152} & 126,240 \\
\hline & $\begin{array}{c}\text { Screed } \\
10 \mathrm{~mm} \mathrm{CFC}\end{array}$ & $\begin{array}{c}16,788 \\
101,952\end{array}$ & & & & & 12,823 & & 13,986 & & & $\begin{array}{l}42,180 \\
63,800\end{array}$ \\
\hline Steel & Reinforcement & - & 244 & 2775 & 15,984 & 2236 & 3408 & 2220 & 15,984 & 2149 & 6634 & 7235 \\
\hline Bitumen & Bitumen & - & - & - & - & - & - & 1554 & 14,652 & - & - & - \\
\hline Masonry & $\begin{array}{l}\text { Bricks } \\
\text { Other }\end{array}$ & - & 7548 & 38,717 & 130,092 & $\begin{array}{c}9612 \\
11,796\end{array}$ & $\begin{array}{l}3728 \\
4575\end{array}$ & 34,632 & 120,546 & $\begin{array}{l}13,741 \\
16,865\end{array}$ & - & $\begin{array}{c}9137 \\
11,213\end{array}$ \\
\hline Timber & Formwork & - & - & - & - & 31,030 & 38,788 & - & - & 2040 & 4782 & - \\
\hline \multirow{2}{*}{$\begin{array}{l}\text { Insulati- } \\
\text { on }\end{array}$} & $\begin{array}{c}\text { Wall } \\
\text { insulation }\end{array}$ & - & - & - & - & - & - & \multirow[t]{2}{*}{222} & \multirow[t]{2}{*}{3330} & - & - & - \\
\hline & $\begin{array}{c}\text { Roof } \\
\text { insulation }\end{array}$ & - & - & - & - & - & - & & & - & - & - \\
\hline
\end{tabular}




\section{References}

1. Thirunavukkarasu, K.; Kanthasamy, E.; Gatheeshgar, P.; Poologanathan, K.; Rajanayagam, H.; Suntharalingam, T.; Dissanayake, M. Sustainable Performance of a Modular Building System Made of Built-Up Cold-Formed Steel Beams. Buildings 2021, 11, 460. [CrossRef]

2. Almahmoud, E.; Doloi, H.K. Identifying the Key Factors in Construction Projects That Affect Neighbourhood Social Sustainability. Facilities 2020, 38, 765-782. [CrossRef]

3. Kamali, M.; Hewage, K. Development of Performance Criteria for Sustainability Evaluation of Modular versus Conventional Construction Methods. J. Clean. Prod. 2017, 142, 3592-3606. [CrossRef]

4. Kamali, M.; Hewage, K. Life Cycle Performance of Modular Buildings: A Critical Review. Renew. Sustain. Energy Rev. 2016, 62, 1171-1183. [CrossRef]

5. Chen, Y.; Okudan, G.E.; Riley, D.R. Sustainable Performance Criteria for Construction Method Selection in Concrete Buildings. Autom. Constr. 2010, 19, 235-244. [CrossRef]

6. Banihashemi, S.; Tabadkani, A.; Hosseini, M.R. Integration of Parametric Design into Modular Coordination: A Construction Waste Reduction Workflow. Autom. Constr. 2018, 88, 1-12. [CrossRef]

7. Pickin, J.; Randell, P.; Trinh, J.; Grant, B. National Waste Report 2018; Department of the Environment and Energy: Canberra, Australia, 2018.

8. Osmani, M. Chapter 15-Construction Waste. In Waste: A Handbook for Management; Letcher, T.M., Vallero, D.A.B.T.-W., Eds.; Academic Press: Boston, MA, USA, 2011; pp. 207-218. ISBN 978-0-12-381475-3.

9. Wang, J.; Li, Z.; Tam, V.W.Y. Critical Factors in Effective Construction Waste Minimization at the Design Stage: A Shenzhen Case Study, China. Resour. Conserv. Recycl. 2014, 82, 1-7. [CrossRef]

10. Jaques, R. Construction Site Waste Generation-The Influence of Design and Procurement. Archit. Sci. Rev. 2000, 43, 141-145. [CrossRef]

11. Bertman, N.; Fuchs, S.; Mischke, J.; Palter, R.; Strube, G.; Woetzel, J. Modular Construction: From Projects to Products; McKinsey \& Company: New York, NY, USA, 2019; pp. 1-34.

12. Lu, W.; Chen, K.; Xue, F.; Pan, W. Searching for an Optimal Level of Prefabrication in Construction: An Analytical Framework. J. Clean. Prod. 2018, 201, 236-245. [CrossRef]

13. Dave, M.; Watson, B.; Prasad, D. Performance and Perception in Prefab Housing: An Exploratory Industry Survey on Sustainability and Affordability. Procedia Eng. 2017, 180, 676-686. [CrossRef]

14. Hu, X.; Chong, H.-Y.; Wang, X. Sustainability Perceptions of Off-Site Manufacturing Stakeholders in Australia. J. Clean. Prod. 2019, 227, 346-354. [CrossRef]

15. Hosseini, M.R.; Martek, I.; Zavadskas, E.K.; Aibinu, A.A.; Arashpour, M.; Chileshe, N. Critical Evaluation of Off-Site Construction Research: A Scientometric Analysis. Autom. Constr. 2018, 87, 235-247. [CrossRef]

16. Johanson, B. Prefab and the Australian Building Sector. Available online: https://builtoffsite.com.au/emag/issue-01/prefabaustralian-building-sector/ (accessed on 4 December 2020).

17. Li, J.; Ding, Z.; Mi, X.; Wang, J. A Model for Estimating Construction Waste Generation Index for Building Project in China. Resour. Conserv. Recycl. 2013, 74, 20-26. [CrossRef]

18. Hammad, A.W.A.; Akbarnezhad, A.; Wu, P.; Wang, X.; Haddad, A. Building Information Modelling-Based Framework to Contrast Conventional and Modular Construction Methods through Selected Sustainability Factors. J. Clean. Prod. 2019, 228, 1264-1281. [CrossRef]

19. Al-Hussein, M.; Manrique, J.; Mah, D. North Ridge $\mathrm{CO}_{2}$ Analysis Report: Com Parison between Modular and on Site Construction; University of Alberta: Edmontom, AB, Canada, 2009; pp. 1-20.

20. Baldwin, A.; Poon, C.-S.; Shen, L.-Y.; Austin, S.; Wong, I. Designing out Waste in High-Rise Residential Buildings: Analysis of Precasting Methods and Traditional Construction. Renew. Energy 2009, 34, 2067-2073. [CrossRef]

21. Aye, L.; Ngo, T.; Crawford, R.H.; Gammampila, R.; Mendis, P. Life Cycle Greenhouse Gas Emissions and Energy Analysis of Prefabricated Reusable Building Modules. Energy Build. 2012, 47, 159-168. [CrossRef]

22. Monahan, J.; Powell, J.C. An Embodied Carbon and Energy Analysis of Modern Methods of Construction in Housing: A Case Study Using a Lifecycle Assessment Framework. Energy Build. 2011, 43, 179-188. [CrossRef]

23. Quale, J.; Eckelman, M.J.; Williams, K.W.; Sloditskie, G.; Zimmerman, J.B. Construction Matters: Comparing Environmental Impacts of Building Modular and Conventional Homes in the United States. J. Ind. Ecol. 2012, 16, 243-253. [CrossRef]

24. Dabirian, S.; Han, S.H.; Lee, J. Stochastic-Based Noise Exposure Assessment in Modular and off-Site Construction. J. Clean. Prod. 2020, 244, 118758. [CrossRef]

25. Ferdous, W.; Bai, Y.; Ngo, T.D.; Manalo, A.; Mendis, P. New Advancements, Challenges and Opportunities of Multi-Storey Modular Buildings-A State-of-the-Art Review. Eng. Struct. 2019, 183, 883-893. [CrossRef]

26. Lawson, R.M.; Ogden, R.G.; Bergin, R. Application of Modular Construction in High-Rise Buildings. J. Archit. Eng. 2012, 18, 148-154. [CrossRef]

27. Kim, D. Preliminary Life Cycle Analysis of Modular and Conventional Housing in Benton Harbor, MI. Ph.D. Thesis, University of Michigan, Ann Arbor, MI, USA, 2008.

28. Navaratnam, S.; Ngo, T.; Gunawardena, T.; Henderson, D. Performance Review of Prefabricated Building Systems and Future Research in Australia. Buildings 2019, 9, 38. [CrossRef] 
29. Wang, M.; Wang, C.C.; Sepasgozar, S.; Zlatanova, S. A Systematic Review of Digital Technology Adoption in Off-Site Construction: Current Status and Future Direction towards Industry 4.0. Buildings 2020, 10, 204. [CrossRef]

30. Jaillon, L.; Poon, C.S. Life Cycle Design and Prefabrication in Buildings: A Review and Case Studies in Hong Kong. Autom. Constr. 2014, 39, 195-202. [CrossRef]

31. Jaillon, L.; Poon, C.S. Sustainable Construction Aspects of Using Prefabrication in Dense Urban Environment: A Hong Kong Case Study. Constr. Manag. Econ. 2008, 26, 953-966. [CrossRef]

32. Jaillon, L.; Poon, C.S.; Chiang, Y.H. Quantifying the Waste Reduction Potential of Using Prefabrication in Building Construction in Hong Kong. Waste Manag. 2009, 29, 309-320. [CrossRef]

33. Tam, C.M.; Tam, V.W.Y.; Chan, J.K.W.; Ng, W.C.Y. Use of Prefabrication to Minimize Construction Waste-a Case Study Approach. Int. J. Constr. Manag. 2005, 5, 91-101. [CrossRef]

34. Li, Z.; Shen, G.Q.; Alshawi, M. Measuring the Impact of Prefabrication on Construction Waste Reduction: An Empirical Study in China. Resour. Conserv. Recycl. 2014, 91, 27-39. [CrossRef]

35. Koskela, L.; Howell, G.; Ballard, G.; Tommelein, I. The foundations of lean construction. In Design and Construction: Building in Value; Routledge: London, UK, 2002; pp. 211-226.

36. Demirkesen, S.; Bayhan, H.G. A Lean Implementation Success Model for the Construction Industry. Eng. Manag. J. 2020, 32, 219-239. [CrossRef]

37. Bajjou, M.S.; Chafi, A.; Ennadi, A.; El Hammoumi, M. The Practical Relationships between Lean Construction Tools and Sustainable Development: A Literature Review. J. Eng. Sci. Technol. Rev. 2017, 10, 170-177. [CrossRef]

38. Hosseini, S.A.A.; Nikakhtar, A.; Wong, K.Y.; Zavichi, A. Implementing lean construction theory into construction processes' waste management. In ICSDC 2011: Integrating Sustainability Practices in the Construction Industry; ASCE: Reston, VA, USA, 2012; pp. 414-420.

39. Guerra, B.C.; Bakchan, A.; Leite, F.; Faust, K.M. BIM-Based Automated Construction Waste Estimation Algorithms: The Case of Concrete and Drywall Waste Streams. Waste Manag. 2019, 87, 825-832. [CrossRef]

40. Bakshan, A.; Srour, I.; Chehab, G.; El-Fadel, M. A Field Based Methodology for Estimating Waste Generation Rates at Various Stages of Construction Projects. Resour. Conserv. Recycl. 2015, 100, 70-80. [CrossRef]

41. Mália, M.; de Brito, J.; Pinheiro, M.D.; Bravo, M. Construction and Demolition Waste Indicators. Waste Manag. Res. 2013, 31, 241-255. [CrossRef]

42. Lu, W.; Yuan, H.; Li, J.; Hao, J.J.L.; Mi, X.; Ding, Z. An Empirical Investigation of Construction and Demolition Waste Generation Rates in Shenzhen City, South China. Waste Manag. 2011, 31, 680-687. [CrossRef]

43. Treloar, G.J.; Gupta, H.; Love, P.E.D.; Nguyen, B. An Analysis of Factors Influencing Waste Minimisation and Use of Recycled Materials for the Construction of Residential Buildings. Manag. Environ. Qual. An Int. J. 2003, 14, 134-145. [CrossRef]

44. Australian Institute of Building Volume 1 NCC- National Construction Code; Australian Institute of Building: Canberra, Australia, 2016.

45. Stratco. Stratco Roofing Battens. Available online: https://www.stratco.com.au/siteassets/pdfs/steel_framing_roof_batten.pdf (accessed on 10 March 2021).

46. Spanman. Weights of Building Materials. Available online: https://www.spanman.net/Members/Technical/Weight-OfBuilding-Materials (accessed on 8 March 2021).

47. MPW. Wall and Ceiling Panels. Available online: http://www.misterplywood.com.au/Products/Wall-and-Ceiling-Panels (accessed on 15 April 2021).

48. Pavertrend. Pavertrend Asphalt/Hot Mix Tonnage Calculator. Available online: https://www.pavertrend.com.au/asphalt/ asphalt-calculator (accessed on 9 March 2021).

49. Knauf. Knauf External Stud Wall Framing Systems. Available online: https://knauf.solutions/products/metal-framing-systems/ knauf-external-stud-wall-framing-systems / (accessed on 9 March 2021).

50. Millform. C-Section Purlin. Available online: https://millform.com.au/c-section-purlins (accessed on 8 March 2021).

51. Fletcher Insulation. Pink Soundbreak High Performance Accoustic Insulation Technical Data Sheet. Available online: https: / /insulation.com.au/wp-content/uploads/2016/04/pink-soundbreak-technical-data-sheet.pdf (accessed on 10 March 2021).

52. Insulfoam. Roof Insulation Systems Consistently Predictable Value. Available online: https://www.insulfoam.com/wp-content/ uploads/2014/04/2016-Roofing_Manual_10-10-16-web.pdf (accessed on 10 March 2021).

53. AustubeMills. Design Capacity Tables for Structural Steel Hollow Sections. Available online: https://www.libertygfg.com/ media/164047/design-capacity-tables-for-structural-steel-hollow-sections.pdf (accessed on 8 March 2021).

54. hySPAN. Span Guide for Residential Framing. Available online: https://www.dindas.com.au/f.ashx/pdf/dindas-hyspan-spantables-oct13.pdf (accessed on 10 March 2021).

55. HardiePanel. Certificate of Physical Properties Hardiepanel Compressed Sheets. Available online: http:/ /www.bigrivergroup. com.au/wp-content/uploads/2016/05/HardiPanel-Physical-Properties.pdf (accessed on 8 March 2021).

56. Johnston, M.P. Secondary Data Analysis: A Method of Which the Time Has Come. Qual. Quant. methods Libr. 2017, 3, 619-626.

57. Boslaugh, S. An Introduction to Secondary Data Analysis. In Secondary Data Sources for Public Health: A Practical Guide; Cambridge University Press: New York, NY, USA, 2007; pp. 2-10.

58. MacInnes, J. An Introduction to Secondary Data Analysis with IBM SPSS Statistics; Sage: Thousand Oaks, CA, USA, 2016; ISBN 1473986958. 
59. Busse, C. A Procedure for Secondary Data Analysis: Innovation by Logistics Service Providers. J. Supply Chain Manag. 2010, 46, 44-58. [CrossRef]

60. Liew, J.Y.R.; Chua, Y.S.; Dai, Z. Steel Concrete Composite Systems for Modular Construction of High-Rise Buildings. Structures 2019, 21, 135-149. [CrossRef]

61. Cameron, P.J.; Di Carlo, N.G. Piecing Together Modular: Understanding the Benefits and Limitations of Modular Construction Methods for Multifamily Development. Ph.D. Thesis, Massachusetts Institute of Technology, Cambridge, MA, USA, 2007. 